\title{
Future Considerations for the Evaluation of Hepatitis C Virus Treatments in Pan-Genotypic Therapy for Noncirrhotic Treatment-Naive Patients
}

\author{
Martin J. Calabrese, PharmD; Lauren M. Hynicka, PharmD, BCPS; \\ Magaly Rodriguez de Bittner, PharmD; and Fadia T. Shaya, PhD, MPH
}

\begin{abstract}
SUMMARY
Given the recent approval of the first pan-genotypic chronic hepatitis C virus (HCV) therapy, managed care, health systems, and clinicians will need to evaluate current practices related to essential laboratory assessments used to select therapy. Historically, clinicians and payers required a battery of tests to determine HCV genotype, viral load, degree of fibrosis, and organ function. In light of current and forthcoming approvals of pangenotypic therapy, clinicians and payers can expect a more competitive marketplace and a downward curve in the price of therapy. Ultimately, this development will lead to the cost of screenings and assessments having an increased role in selecting an optimal HCV therapy.
\end{abstract}

J Manag Care Spec Pharm. 2018;24(1):20-22

Copyright $\odot 2018$, Academy of Managed Care Pharmacy. All rights reserved.

$\mathrm{I}$ $\mathrm{n}$ the current environment of highly effective and welltolerated curative agents for chronic hepatitis $\mathrm{C}$ virus (HCV), guidelines have recommended the broad use of direct-acting antivirals (DAAs) for the vast majority of individuals with chronic HCV. ${ }^{1}$ Until the approval of sofosbuvir/velpatasvir, the first pan-genotypic DAA, all other currently recommended DAA regimens had segmented the market around a patient's HCV genotype, which can include $1(\mathrm{a}$ or b), $2,3,4,5$, or 6 . In the United States, the vast majority of cases are genotype la or $1 b .^{1-3}$

Before June 2016, approved U.S. guideline-recommended chronic HCV therapies encompassed a variety of options that included elbasvir/grazoprevir, daclatasvir + sofosbuvir ledipasvir/sofosbuvir, paritaprevir/ribavirin/ombitasvir + dasabuvir, paritaprevir/ribavirin/ombitasvir, and simeprevir + sofosbu-

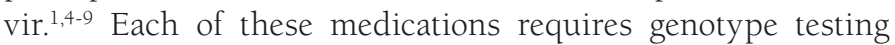
plus a variety of additional testing and considerations in accordance with labeling approved by the U.S. Food and Drug Administration (FDA), including determining resistanceassociated variants (RAVs), drug/drug interactions, prognosis of liver disease assessed by Child-Pugh, and cirrhosis with or without compensation. The results of these assessments may indicate that further therapeutic action should be considered. For example, Child-Pugh class $C$ is indicative of decompensated cirrhosis, which warrants the addition of weight-based ribavirin therapy. After considering drug-drug interactions and other clinical factors in the setting of pan-genotypic sofosbuvir/ velpatasvir, genotype testing, along with other commonly used laboratory and diagnostic assessments, may not be required (Table 1). ${ }^{10}$

Given the wide variety of guideline-directed therapies that are equally relatively safe and effective and the likelihood of additional pan-genotypic agents in the future, it is important to be mindful of the minimum required screenings and their costs in order to efficiently use the DAA therapeutic options available to patients. Additional pan-genotypic medication in the pipeline from a number of manufacturers will lead to a downward curve of the medication price. Subsequently, this downward curve would require health systems, clinicians, and payers to be mindful of the laboratory and assessment costs before and during HCV therapy. Considering the complexities involved in the determination of the true price for medications (e.g., manufacturer rebates), the authors intentionally excluded the cost of therapy from cost of laboratory screenings and assessments.

Laboratory screenings and assessments required to properly evaluate the on-label use of current guideline-directed therapies are compiled in Table 1., ${ }^{1,4-9}$ This table is not comprehensive and highlights the laboratory and screening assessment likely required for noncirrhotic treatment-naive patients. Screenings and assessments to verify that a patient is noncirrhotic are included for completeness. In addition, as more pan-genotypic agents come to market, clinicians, health systems, and payers need to be mindful that the screenings and assessments required before and shortly after initiating treatment vary between therapies. The fee-for-service costs per the Centers for Medicaid and Medicare Services are included for reference. ${ }^{11,12}$

According to FDA-approved prescribing information for various therapies, determination of RAVs only needs to be considered for elbasavir/grazoprevir and daclatasvir + sofosbuvir regimens in patients with genotypes la and 3. Although degree of fibrosis/cirrhosis may not be specifically required for some agents, such as elbasvir/grazoprevir and ledipasvir/sofosbuvir, it may be considered best practice to determine the degree of cirrhosis/fibrosis, since it is pertinent to the overall clinical picture. In addition, determination of hepatic prognosis measured by Child-Pugh and need for additional screening for complications of cirrhosis such as esophageal varices and hepatocellular carcinoma may be warranted. 


\begin{tabular}{|c|c|c|c|c|c|c|c|}
\hline \multirow[b]{2}{*}{$\begin{array}{l}\text { Laboratory Screenings } \\
\text { and Assessments }\end{array}$} & \multirow[b]{2}{*}{ Cost $^{\mathrm{a}}$ U.S. $\$$} & \multicolumn{6}{|c|}{ Treatments } \\
\hline & & $\begin{array}{l}\text { Elbasvir/ } \\
\text { grazoprevir }\end{array}$ & $\begin{array}{l}\text { Daclatasvir }+ \\
\text { sofosbuvir }\end{array}$ & $\begin{array}{l}\text { Ledipasvir/ } \\
\text { sofosbuvir }\end{array}$ & PrOD or PrO & $\begin{array}{l}\text { Simeprevir }+ \\
\text { sofosbuvir }\end{array}$ & $\begin{array}{l}\text { Sofosbuvir/ } \\
\text { velpatasvir }\end{array}$ \\
\hline Genotype & 473.91 & $\mathrm{X}$ & $\mathrm{X}$ & $\mathrm{X}$ & $\mathrm{X}$ & $\mathrm{X}$ & \\
\hline RAV & 177.56 & $\mathrm{X}^{\mathrm{b}}$ & $\mathrm{X}^{\mathrm{c}}$ & & & & \\
\hline \multicolumn{8}{|l|}{ Degree of fibrosis } \\
\hline FibroSure & 80.62 & $\mathrm{X}$ & $\mathrm{X}$ & $\mathrm{X}$ & $\mathrm{X}$ & $\mathrm{X}$ & $\mathrm{X}$ \\
\hline Ultrasound & 124.24 & $\mathrm{X}$ & $\mathrm{X}$ & $\mathrm{X}$ & $\mathrm{X}$ & $\mathrm{X}$ & $\mathrm{X}$ \\
\hline \multicolumn{8}{|l|}{ Child-Pugh } \\
\hline Total bilirubin & 6.83 & $\mathrm{X}$ & $X$ & $X$ & $X$ & $X$ & $X$ \\
\hline Serum albumin & 6.74 & $\mathrm{X}$ & $\mathrm{X}$ & $\mathrm{X}$ & $\mathrm{X}$ & $\mathrm{X}$ & $\mathrm{X}$ \\
\hline Prothrombin time & 5.37 & $\mathrm{X}$ & $\mathrm{X}$ & $\mathrm{X}$ & $\mathrm{X}$ & $\mathrm{X}$ & $\mathrm{X}$ \\
\hline ALT & 7.22 & $\mathrm{X}$ & & & $\mathrm{X}$ & & \\
\hline $\mathrm{SCr}$ & 12.88 & & $\mathrm{X}$ & $\mathrm{X}$ & & $\mathrm{X}$ & $\mathrm{X}$ \\
\hline $\mathrm{CBC}$ & 11.91 & $\mathrm{X}^{\mathrm{d}}$ & & & $\mathrm{X}^{\mathrm{e}}$ & & \\
\hline \multicolumn{8}{|c|}{ Costs compared with sofosbuvir/velpatasvir, U.S. \$ } \\
\hline If RAV required & & 894.40 & 888.15 & 710.59 & 716.84 & 888.15 & 236.68 \\
\hline All other genotypes ${ }^{f}$ & & 704.93 & 710.59 & 710.59 & 704.93 & 888.15 & 236.68 \\
\hline \multicolumn{8}{|c|}{ 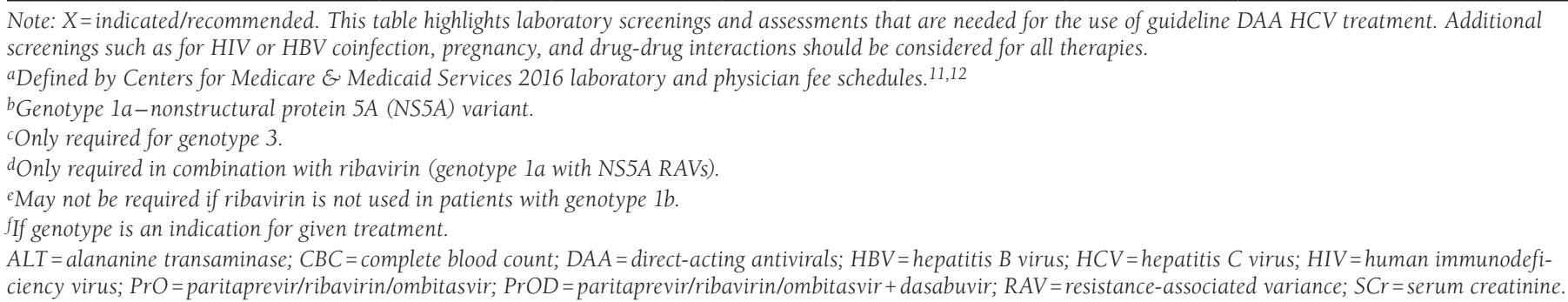 } \\
\hline
\end{tabular}

As outlined in Table 1, sofosbuvir/velpatasvir requires the least amount of laboratory screenings and assessments. Costs for screenings and assessments in excess of sofosbuvir/ velpatasvir are calculated in the last row of Table 1 for each guideline-recommended therapy.

Upon confirmation of a chronic HCV diagnosis, clinicians should be mindful of therapeutic options before ordering further laboratory screenings and assessments. Given current availability, likelihood of additional pan-genotypic agents, and the presence of multiple equally relatively effective therapeutic options, it may be prudent to exercise caution in implementing a one-size-fits-all "pan-assessment" when evaluating therapies. This consideration becomes particularly meaningful in situations where therapeutic choices are limited to institutional or insurance formularies and with future approvals of additional pan-genotypic HCV therapies.

In a scenario with at least 2 therapeutic options, it is reasonable for clinicians and health systems to obtain the following laboratory screenings and assessments regardless of which genotype-specific DAA therapy is under consideration: genotype, cirrhosis/fibrosis, and assessments required to determine the Child-Pugh score. All other screenings and assessments are dependent on subsequent genotype determination and available therapeutic options for clinicians after weighing factors of a patient's insurance and health system formularies. Unless pan-genotypic therapies are the only therapeutic option, HCV genotype should always be determined in order to identify and evaluate other therapeutic options in treatment-naive noncirrhotic patients.

\section{Authors}

MARTIN J. CALABRESE, PharmD; LAUREN M. HYNICKA, PharmD, BCPS; MAGALY RODRIGUEZ DE BITTNER, PharmD; and FADIA T. SHAYA, PhD, MPH, University of Maryland School of Pharmacy, Baltimore.

AUTHOR CORRESPONDENCE: Martin J. Calabrese, PharmD, Dept. of Pharmacy Practice and Sciences, University of Maryland School of Pharmacy, 110 N. Pine St., Rm 109C, Baltimore, MD 21201. Tel.: 847.322.2493; E-mail: mcalabrese@umaryland.edu. 


\section{DISCLOSURES}

No outside funding supported this study. The authors have nothing to disclose.

All authors contributed to study concept and design. Calabrese took the lead in data collection, along with Shaya. Data interpretation was performed by Calabrese and Hynicka, along with Rodriguez de Bittner and Shaya. The manuscript was written and revised by Calabrese and Hynicka, along with Rodriguez de Bittner and Shaya.

\section{ACKNOWLEDGMENTS}

The authors thank medical writer Kelly Calabrese, BS, for her editorial input.

\section{REFERENCES}

1. American Association for the Study of Liver Diseases, Infectious Diseases Society of America. HCV guidance: recommendations for testing, managing, and treating hepatitis C. Available at: http://www.hcvguidelines.org. Accessed October 27, 2017.

2. Blatt LM, Mutchnick MG, Tong MJ, et al. Assessment of hepatitis $C$ virus RNA and genotype from 6807 patients with chronic hepatitis $C$ in the United States. J Viral Hepat. 2000;7(3):196-202.

3. Nainan OV, Alter MJ, Kruszon-Moran D, et al. Hepatitis C virus genotypes and viral concentrations in participants of a general population survey in the United States. Gastroenterology. 2006;131(2):478-78.

4. Zepatier (elbasvir and grazoprevir) tablets, for oral use. Merck \& Co. Revised February 2017. Available at: https://www.merck.com/product/usa/ pi_circulars/z/zepatier/zepatier_pi.pdf. Accessed October 27, 2017.
5. Daklinza (daclatasvir) tablets, for oral use. Bristol-Myers Squibb. Revised February 2017. Available at: https://www.accessdata.fda.gov/drugsatfda_ docs/label/2017/206843s006lbl.pdf. Accessed October 27, 2017.

6. Harvoni (ledipasvir and sofosbuvir) tablets, for oral use. Gilead Sciences Revised October 2014. Available at: https://www.accessdata.fda.gov/drugsatfda_docs/label/2014/205834s000lbl.pdf. Accessed October 27, 2017.

7. Viekira XR (dasabuvir, ombitasvir, paritaprevir, and ritonavir). AbbVie. Revised March 2017. Available at: http://www.rxabbvie.com/pdf/viekiraxr_ pi.pdf. Accessed October 27, 2017.

8. Technivie (ombitasvir, paritaprevir and ritonavir) tablets, for oral use. AbbVie. Revised March 2017. Available at: https://www.rxabbvie.com/pdf/ technivie_pi.pdf. Accessed October 27, 2017.

9. Olysio (simeprevir) capsules, for oral use. Revised May 2017. Janssen Products. Available at: https://www.olysio.com/shared/product/olysio/ prescribing-information.pdf. Accessed October 27, 2017.

10. Epclusa (sofosbuvir and velpatasvir) tablets, for oral use. Gilead Sciences. Revised August 2017. Available at: https://www.gilead.com/ /media/files/ $\mathrm{pdfs} / \mathrm{medicines/liver-disease/epclusa/epclusa \_ pi.pdf?la=en.} \mathrm{Accessed}$ October 27, 2017

11. Centers for Medicare \& Medicaid Services. Clinical laboratory fee schedule. Available at: https://www.cms.gov/Medicare/Medicare-Fee-for-ServicePayment/ClinicalLabFeeSched/index.html?redirect=/ClinicalLabFeesched. Accessed October 27, 2017.

12. Centers for Medicare \& Medicaid Services. Physician fee schedule. Available at: https://www.cms.gov/Medicare/Medicare-Fee-for-ServicePayment/PhysicianFeeSched/index.html?redirect=/PhysicianFeeSched. Accessed October 27, 2017. 